\title{
Effects of Seedling Spacing on Growth parameters and Yield attributes of three Cowpea Varieties
}

\section{BANDUSHUBWENGE Denis ${ }^{* 1}$, KWIZERA Chantal ${ }^{2}$, MBONIHANKUYE Cyrille ${ }^{3}$}

${ }^{1}$ University of Burundi, Faculty of Agriculture and Bio Engineering, Department of vegetal productions Sciences, B.P 2940 Bujumbura, Burundi

${ }^{2}$ University of Burundi, Faculty of Agriculture and Bio Engineering, Department of Environment

Sciences and Technologies, B.P 2940 Bujumbura, Burundi

${ }^{3}$ Agronomic Sciences Institute of Burundi (ISABU)

\begin{abstract}
Seedling spacing is an important factor which plays a vital role in boosting yield. Many plants are very sensitive to this factor especially cowpea, a key plant with major benefits to households nutrition and health around the world. However, cowpea seedling spacing still a factor that requires adjustment in many countries, especially in Burundi where this crop is not yet well domesticated, with cultivation under traditional systems, inadequate planting methods coupled with lack of different varieties. An experiment was carried out in three blocks completely randomized with three replications for each. It has considered three cowpea varieties (local and Tanzanian varieties (Katumani and Vuli)) and four seedling spacing (SS): SS1 (50cmX40cm); SS2 $(50 \mathrm{cmX} 50 \mathrm{~cm}) ; S S 3(60 \mathrm{cmX} 40 \mathrm{~cm})$ and SS4 $(60 \mathrm{cmX} 50 \mathrm{~cm})$. Results highlighted Seedling spacing SS1 as the effective seedling spacing which could effectively improve all studied growth parameters and yield attributes for local and katumani varieties. It has effectively improved plant height; leaf area index; number of flowers, pods and grains. Moreover, this seedling spacing has also recorded enhanced crop yield, whence it has been considered as the most effective seedling spacing, especially for local (L) and katumani (K), varieties which could be considered for cultivation in Burundi. Regarding Vuli variety, although it has also recorded improved yield, data variabilities was observed, whence further studies were recommended for more clarification.
\end{abstract}

Keywords: Seedling Spacing, Growth parameters, Yield Parameters, Local Cowpea Variety, Katumani Cowpea Variety, Vuli Cowpea Variety.

\section{INTRODUCTION}

Seedling spacing affects the growth, size, yield as well as the quality of the production ${ }^{[1-2]}$. It is a factor which can play an important role in boosting yield. Many studies revealed that closer spacing may causes mutual shading, lodging, insect pest infestation due to more intra-specific competition ${ }^{[3-4]}$. Furthermore, it is a major character that even broadcast-sown consider as highlighted by foregoing research which demonstrated improved outplanting performance through wider spacing [5-6-7-8]. Moreover, spacing improves convenience for activities such as weeding, nutrient application or harvesting. With required seedling

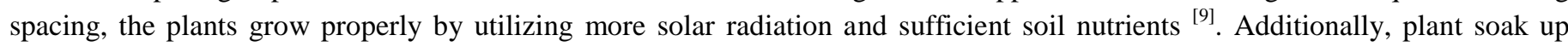
water and nutrients without competing with other nearby plants. On one hand, Hoque et al. (1979) and Kumar et al. (1998) highlighted highest yield with a spacing of 20x10 $\mathrm{cm}^{[2-10]}$, Gupta and Gaffer (1980) at $15 \times 10 \mathrm{~cm}^{[11]}$, Islam (1988) at 10x9 $\mathrm{cm}^{[12]}$, Badaruddin and Haque (1977) at 10x30 cm and Rashid and Rashid (1976) at 20x10 $\mathrm{cm}$ in a single row system ${ }^{[1]}$. On the other hand, Rashid and Rashid (1976) reported the highest yield at $10 x 10 \mathrm{~cm}$ in a multiple row system ${ }^{[13]}$, while Singh and Jain (1984) revealed highest yield at $10 \times 30 \mathrm{~cm}$ seedling spacing ${ }^{[14]}$. Several researchers in many countries have shown that plant spacing had profound effects on crop growth and yield ${ }^{[15-16-10]}$. Although wider spacing gave highest yield, proper spacing ensures optimum plant growth through adequate utilization of moisture, light, spacing and nutrients ${ }^{[17]}$. Overall, crops are very sensitive to seedling spacing, especially cowpea, a plant of major importance, known as grain legume originated in the African continent. However legumes are consumed worldwide as an alternative source of proteins, since they are rich in amino acids like lysine and tryptophan and they are much 
cheaper than animal proteins ${ }^{[18]}$. Legumes are an excellent source of many essential nutrients, including vitamins, minerals, fibers, antioxidants and other bioactive compounds ${ }^{[19-20]}$, like enzyme inhibitors, lectins, phytates, oligosaccharides and phenolic compounds that play metabolic roles in humans consuming these foods frequently ${ }^{[21]}$. Beyond that, the legume, cowpea, is a strategic culture for the promotion of food security and health with about $24 \%$ protein, $62 \%$ soluble carbohydrate and small amount of other nutrients. It provides a nutritious grain and a less expensive source of protein for both rural and urban poor consumers ${ }^{[22]}$. Apart from its role in controlling soil erosion and fixing atmospheric nitrogen into the soil, thereby reducing nitrogen requirement for its growth ${ }^{[23]}$; cowpea is adapted to stressful environment where other crops either fail or do not perform well. Whence households harvest leaves and grains for consumption or sale during the dry season when grain reserves from the previous cereal harvests have been depleted and current crops are not ready for harvest. Despite these advantages, this plant is not well domesticated in Burundi, cultivation is mainly under traditional systems, yield in farmers' fields are low due to inadequate planting systems coupled with severe attacks of pest, diseases, and inappropriate cultivars. This study has been undertaken to assess the seedling spacing which could improve growth and yield parameters of three cowpea varieties and to identify the most productive varieties which can be recommended to Burundian population.

\section{MATERIALS AND METHODS}

\subsection{Experiment design}

The experiment was carried out in plots of Burundi Agricultural Sciences Institute (ISABU) at Bujumbura in three blocks completely randomized with three replications for each. These blocks were divided into 16 plots meaning a total of 48 units, while the plots were ranged following the used seedling spacing (SS): SS1 $(50 \mathrm{cmX} 40 \mathrm{~cm}) ; \mathrm{SS} 2(50 \mathrm{cmX} 50 \mathrm{~cm}) ; \mathrm{SS} 3(60 \mathrm{cmX} 40 \mathrm{~cm})$ and SS4 $(60 \mathrm{cmX} 50 \mathrm{~cm})$.

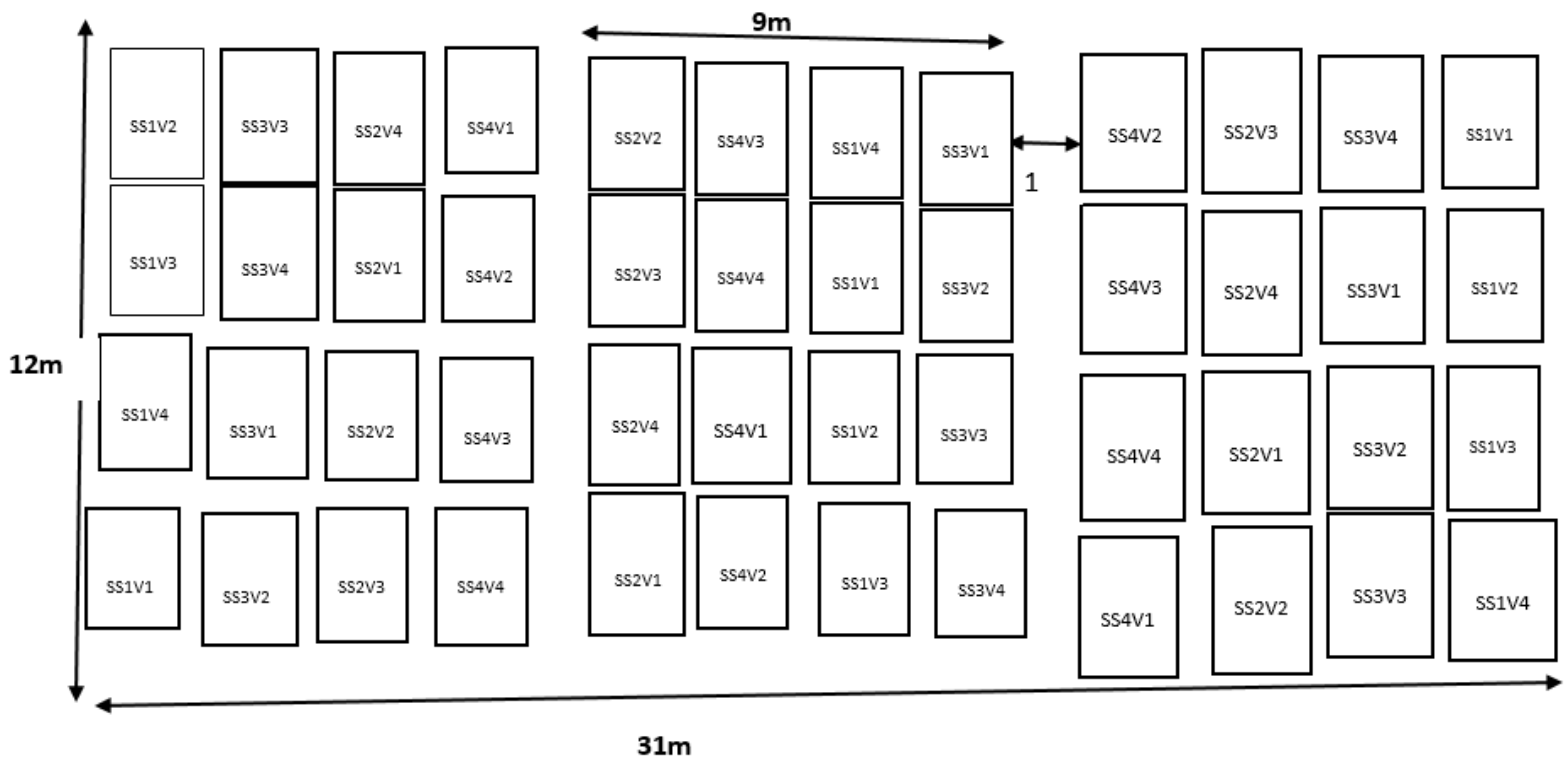

Photos 1. Experiment design

The experiment has considered three varieties: Local variety (L), and tanzanian varieties: Katumani: (K) and Vuli (V), whereas recorded parameters were leaf area, plant height, number of flowers and pods, as well as the yield. During the experiment, Dimethoate and Mancozeb were applied to control insects and damping-off respectively.

\subsection{Statistical analysis}

For data analysis, advanced Excel and GENSTAT Discovery 16 have been used. Comparisons between treatments were conducted through Newman-Keuls test at $\mathrm{P}<0.05$, while figures and tables were made by using Excel.

\section{RESULTS}

\subsection{Growth parameters}

\subsubsection{Plant height}

Results Plant height shows non-significant difference between seedling spacing as can be seen in the table 1. Considering Local variety (L), the first tallest plant was recorded for SS1 $(50 \mathrm{cmX} 40 \mathrm{~cm})$ with $52.77 \mathrm{~cm}$, the second of $51.33 \mathrm{~cm}$ was obtained for SS2 
$(50 \mathrm{cmX} 50 \mathrm{~cm})$ and the smallest for SS3 $(60 \mathrm{cmX} 40 \mathrm{~cm})$ and SS4 $(60 \mathrm{cmX} 50 \mathrm{~cm})$ with $45.5 \mathrm{~cm}$ and $45.57 \mathrm{~cm}$ and $42.4 \mathrm{~cm}$ respectively. The same trend was observed for Katumani Variety (K), where the maximum height was observed for SS1 with 57.4 $\mathrm{cm}$, the following for SS2 of $50.4 \mathrm{~cm}$ and the minimum for SS4 and SS3 with $47.13 \mathrm{~cm}$ and $46.43 \mathrm{~cm}$ respectively.

Table 1. Effects of seedling spacing on plant height

\begin{tabular}{llll}
\hline & L & K & V \\
\hline SS1 & $52.77 a$ & $57.4 a$ & $53.77 a$ \\
SS2 & $51.33 a$ & $50.4 a$ & $49.77 a$ \\
SS3 & $42.4 a$ & $46.43 a$ & $55.23 a$ \\
SS4 & $45.57 a$ & $47.13 a$ & $45.37 a$ \\
\hline
\end{tabular}

L: Local variety; K: Katumani variety, $V:$ Vuli variety

SS1: First seedling spacing; SS2: Second seedling spacing; SS3: Third seedling spacing; SS4: Fourth seedling spacing.

Regarding to Vuli variety (V), the highest plant of $55.23 \mathrm{~cm}$ was observed for SS3, while SS1 got the second highest value of $53.77 \mathrm{~cm}$ and minimum for SS4 with $45.37 \mathrm{~cm}$. although SS3 recorded the first highest plant, it did not show significant difference comparatively to others.

\subsubsection{Leaf area index response to seedling spacing}

Leaf area index (LAI) is an important parameter in plant ecology due to its relation with the photosynthesis ${ }^{[24]}$. It is a dimension quantity that characterizes plant canopies. Defined as the leaf area per unit ground surface area (LAI = leaf area / ground area), leaf area index is the measure of the photosunthetic active area. In the current study, its evolution was summed up in Figure 1.

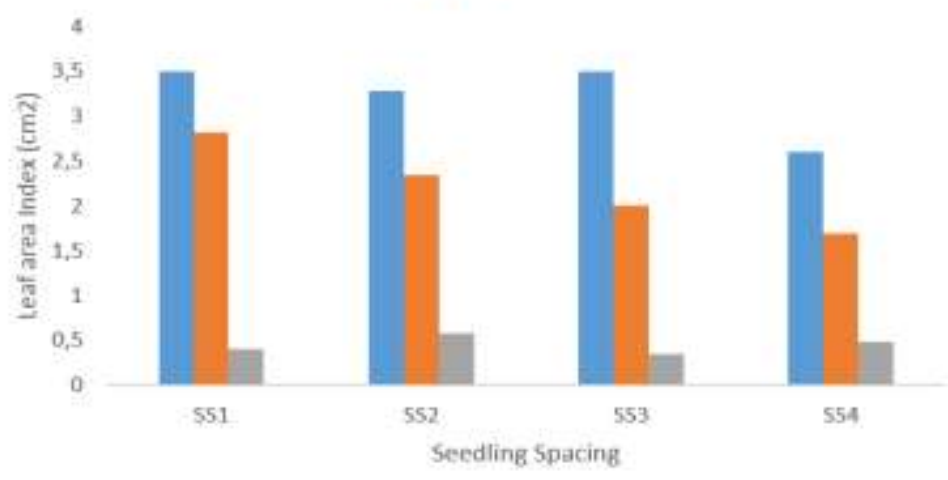

Figure 1. Leaf area index response to seedling spacing

Considering L, maximum leaf area index (LAI) was observed for SS1 with $3.5 \mathrm{~cm}^{2}$, while the following LAI value of $3.5 \mathrm{~cm}{ }^{2}$ was recorded for SS3 and minimum for SS4 by $2.6 \mathrm{~cm}^{2}$. Simiraly, the LAI optimum value for K variety was recorded for SS1 (2.83 $\mathrm{cm}^{2}$ ), and lowest for SS4 $\left(1.7 \mathrm{~cm}^{2}\right)$. Regarding to V variety, the highest LAI was observed for SS2 with $0.58 \mathrm{~cm}^{2}$ and minimum for $\mathrm{SS} 3$ of $0.35 \mathrm{~cm}^{2}$.

\subsection{Comparison of varieties responses on growth parameters}

Results on comparison of varieties responses on growth parameters showed significant difference as can be seen in table 2 . Cleary, considering plant height at the first time (at the appearance of the first trifoliate leaf) the highest plant was observed for $\mathrm{K}$ variety with $11.2 \mathrm{~cm}$. It significantly differed to $\mathrm{K}$ and $\mathrm{L}$ with a probability value of $\mathrm{p}<0.05$. It was followed by $\mathrm{K}$ of $10.61 \mathrm{~cm}$ which significantly differed from $\mathrm{V}$, the variety with lowest value of $9.95 \mathrm{~cm}$. 
International Journal of Advances in Scientific Research and Engineering (ijasre), Vol 6 (9), September -2020

Table 2. Comparison of varieties responses on growth parameters

\begin{tabular}{llll}
\hline \multirow{2}{*}{ Variety } & $\begin{array}{l}\text { PH at the apperance of the } \\
\text { first trifoliate leaf }(\mathrm{cm})\end{array}$ & $\begin{array}{l}\text { PH at the apperance of the } \\
\text { first flower }(\mathrm{cm})\end{array}$ & LAI $\left(\mathrm{cm}^{2)}\right.$ \\
\hline Locale & $10.61 \mathrm{a}$ & $37.59 \mathrm{a}$ & $3.09 \mathrm{a}$ \\
Katumani & $11.27 \mathrm{~b}$ & $36.08 \mathrm{a}$ & $2.26 \mathrm{~b}$ \\
Vuli & $9.95 \mathrm{c}$ & $41.82 \mathrm{~b}$ & $0.45 \mathrm{c}$ \\
\hline
\end{tabular}

PH: Plant Height; LAI: Leaf Area Index

At the second time, with the appearance of the first flower, the trend changes, the tallest plant was observed for $\mathrm{V}(41.82 \mathrm{~cm})$, which significantly differed to $\mathrm{L}(37.59 \mathrm{~cm})$ and $\mathrm{K}(36.08 \mathrm{~cm})$. Considering leaf area index, the maximum was recorded for $\mathrm{L}$ variety with $3.09 \mathrm{~cm}^{2}$ and significantly differed from others. It was followed by $\mathrm{K}$ with $2.26 \mathrm{~cm}^{2}$, whereas the minimum was recorded for $\mathrm{V}$ with $0.45 \mathrm{~cm}^{2}$. This testify the highest value observed for $\mathrm{V}$, which cannot assimilate enough light to synthesize sufficient nutrient for its growth and development whence tallest plant as its adaptation to get sufficient light to synthesize nutrients.

\subsection{Yield and Yield attributing characters}

\subsubsection{Effects of Seedling Spacing on flowers number (FN) per plant}

Flower is the basis on which yield largely dependent ${ }^{[25]}$. Lim and Hamdan (1984) reported increased plant yield for plant with higher flowers number ${ }^{[26]}$, while Lee et al. (1972) reported a reduced yield for plant with lower flowers number ${ }^{[27]}$. Overall, this last represent the reproductive unit that turned to pods and is an indicator of plant yield projection, whence it has been recorded and displayed in figure 2.

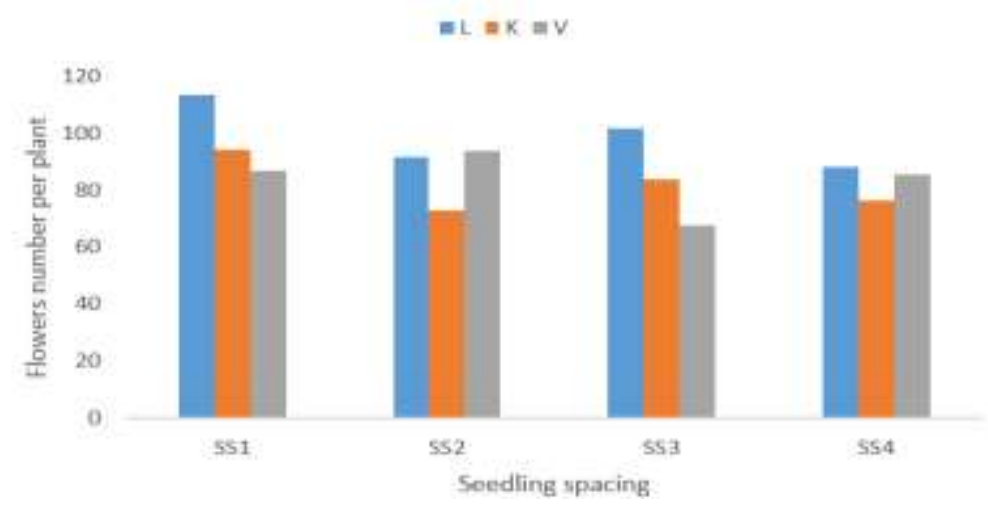

Figure 2. Effects of Seedling Spacing on flowers number (FN) per plant

Regarding to L, the maximum FN per plant was observed for SS1 (113 flowers), followed by SS3 (101 flowers), while the minimum was recorded for SS4 (88 flowers). The same FN evolution trend was observed for K where the first highest FN of 94 flowers was recorded for SS1, the second for SS3 with 84 flowers, and the last of 77 flowers for SS2. Considering V, the optimum FN was recorded for SS2 with 94 flowers, followed by SS1 of 87 flowers, and minimum for the SS3 of 68 flowers per plant.

\subsubsection{Influences of Seedling Spacing on pods number per plant}

Pods number has been assessed in this study as can be seen in figure 3 .

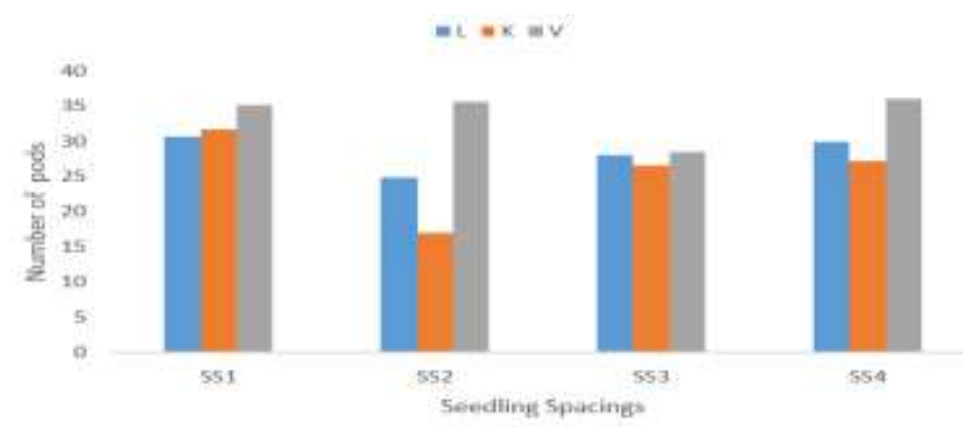

Figure 3. Influences of Seedling Spacing on pods number per plant 
Considering L variety, the SS1 recorded the highest number of 31 pods per plant, followed by SS4 with 30 pods, while SS2 obtained the minimum of 25 pods. The same trend was observed for K, where the first highest value was observed for SS1 (32 pods) and presented significant difference $(\mathrm{P}<0.05)$ from others. The second highest value was recorded for SS3 and SS4, both received the same value of 27 pods per plant and significantly differed from the SS2, the seedling spacing with minimum value of 17 pods. For V variety, the highest number was observed for SS4, 36 pods, followed by SS 1 , 35 pods, while the minimum of 29 pods was obtained by SS3.

\subsubsection{Effects of Seedling Spacing on grains number per pod}

Based on figure 4, Seedling Spacing did not significantly influenced the grains number per pod. However means grains value differed following the implemented Seedling Spacing. Specifically, the highest number of grains for L was recorded by SS1 of 19 grains. It was followed by SS4 with 18 grains per pod, while SS3 and SS2 showed minimum value with both 17 grains per pod.

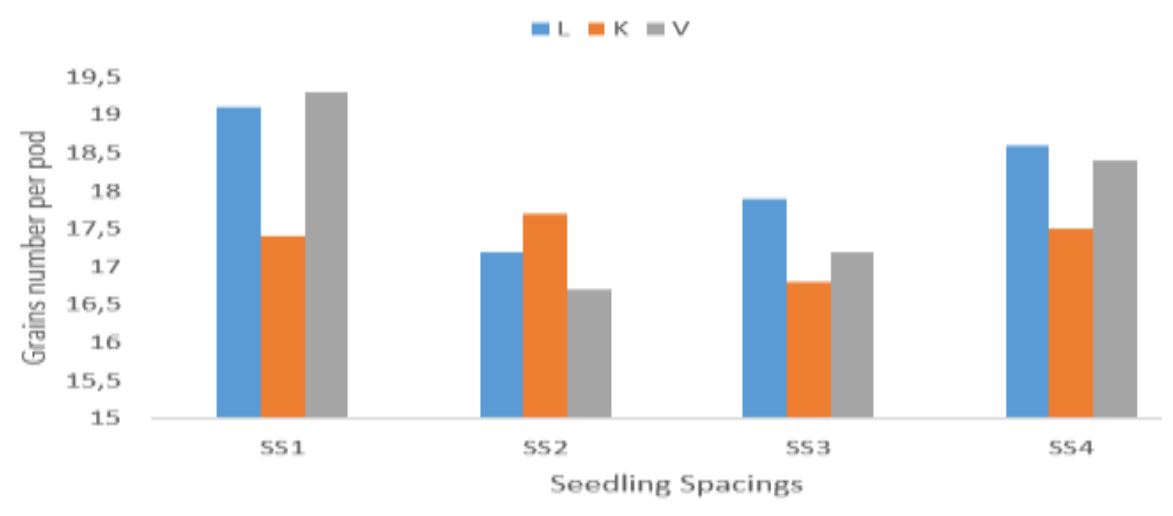

Figure 4. Influences of Seedling Spacing on grains number per pod

The same trend was observed for V, where SS1 showed plant with maximum value of 19 grains per pod, followed by SS4 of 18 grains per pod and minimum both SS2 and SS3 which obtained the same value of 17 grains per pod. Regarding to K, the maximum value of grains was observed for both implement seedling spacing SS2 and SS4 which recorded the same value of 18 grains per pod, while the minimum of 17 grains per pod was observed for both SS1 and SS3.

\subsubsection{Effects of Seedling Spacing on plant yield}

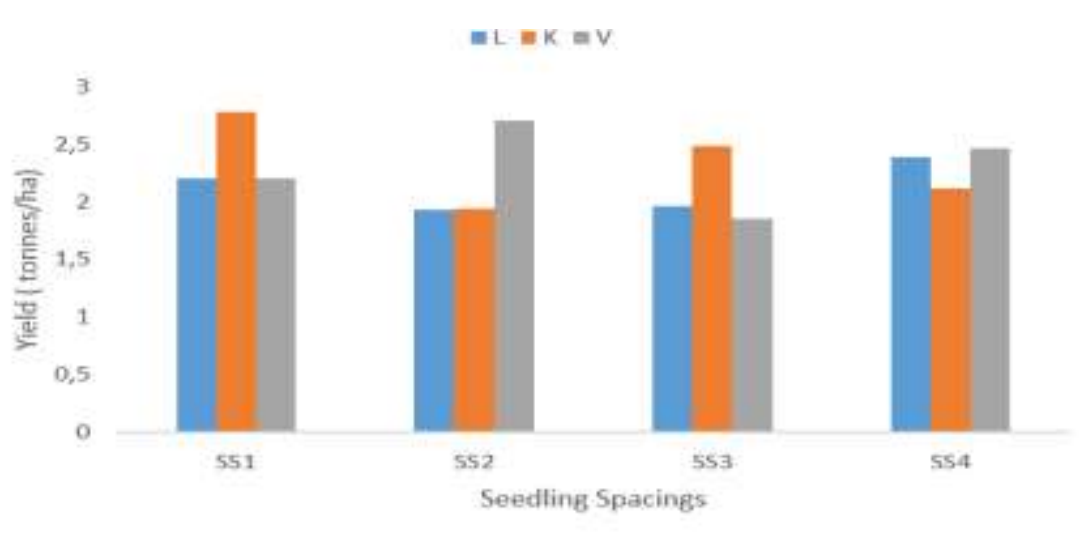

Figure 5. Effects of seedling Spacing on plant yield

The outcomes displayed in figure 5 highlighted significant effects of seedling spacing on plant yield. Clearly, the maximum yield was observed for SS4 (2.3 t/ha) and SS1 (2.2t/ha) which did not show significant difference from SS2 (1.96 t/ha) and SS3 (1.93 t/ha). For K variety, the optimum yield was obtained for SS1 with $2.7 \mathrm{t} / \mathrm{ha}$, while the minimum was recorded for SS2. Regarding to V, the highest value was observed for SS2 of $2.7 \mathrm{t} / \mathrm{ha}$, followed by SS4 and SS1 with 2.46 and 2.2 t/ha respectively. The lowest value of $1.85 \mathrm{t} / \mathrm{ha}$ was observed for SS3 seedling spacing. Although these seedling spacing did not show significant difference, varieties showed significant difference as well as interaction between variety and treatment. 


\subsubsection{Comparison of varieties responses on yield parameters}

Responses of varieties on yield parameters were displayed in table 3. Significant difference between varieties with a probability value $\mathrm{p}<0.05$ was observed for all studied parameters.

Table 3 Comparison of varieties responses on yield parameters

\begin{tabular}{lllll}
\hline Variety & Flowers number & Pods number & $\begin{array}{l}\text { grains } \\
\text { number }\end{array}$ & $\begin{array}{l}\text { Yield } \\
(\text { t/ha })\end{array}$ \\
\hline Locale & $99 a$ & $28 a$ & $19 a$ & 2.101 a \\
Katumani & $82 b$ & $36 a$ & $17 b$ & $2.335 a$ \\
Vuli & $84 b$ & $34 b$ & $18 a$ & $2.583 a$ \\
\hline
\end{tabular}

Specifically, considering Flowers number, maximum flowers was observed for L, 99 flowers, and significantly differed to K, 82 flowers, and V, 84 flowers, varieties with little discrepancy. The same pattern was observed for grains number as can be seen in table 3. Results highlighted maximum grains for L (19 grains), followed by V (18 grains) and minimum for K (17 grains) regarding to yield, the highest was obtained for V (2.583 t/ha), followed by K (2.335 t/ha) and lower in L ( $2.101 \mathrm{t} / \mathrm{ha})$. However there was no significance difference, the value recorded for this yield parameters were all in the same variation range.

\section{DISCUSSION}

Seedling spacing had played great role in improving growth parameters. All the analyzed parameters were maximum for SS1 $(50 \times 40 \mathrm{~cm})$ comparatively to SS2 $(50 \mathrm{cmX} 50 \mathrm{~cm}) ; \mathrm{SS} 3(60 \mathrm{cmX} 40 \mathrm{~cm})$ and SS4 $(60 \mathrm{cmX} 50 \mathrm{~cm})$, especially for local (L) Variety and Katumani (K). This was maybe due to sufficient available nutrients, light penetration, moisture and space for better crop establishment. Moreover, this may be attributed to adequate seedling spacing which reduce plant competition and favors larger leaf area, whence increased net photosynthetic assimilates resulting in vigorous growth through synthesis of more nutrients that plant need for growth. This support the results of Zubeldia and Gases (1977) who reported optimum plant growth through adequate spacing ${ }^{[17]}$. This seedling spacing SS1 has also effectively influenced yield attributes. It enhanced number of flowers, pods and grains which obviously indicate crop yield enhancement. This endorses foregoing researchers which affirmed that plant spacing had profound effects on the growth and yield ${ }^{[15-17-10]}$. In the present study, although there was no significance difference, the maximum value for almost tested parameters was observed for seedling spacing SS1 comparatively to others, whence it has been considered as the effective seedling spacing for cowpea especially for local (L) and katumani variety (K).

\section{CONCLUSION}

The results highlighted better effects of SS1 $(50 \times 40 \mathrm{~cm})$ seedling spacing for local (L) and Katumani varieties (K). It has played an important role in plant growth parameters by effectively increasing the leaf area index, plant height and flowers number. Furthermore, this implemented seedling spacing SS1 could efficiently improve pods number per plant, yield and grains number. This suggested SS1 seedling spacing as the effective spacing which can be used especially for local and Katumani cowpea varieties. However further studies are recommended for vuli variety (V) which showed more data variabilities.

\section{REFERENCES}

[1] Badaruddin, M. and Haque, M. A. 1977. Effect of time of planting and spacing on the yield of onion (Allium cepa L.). Bangladesh Hort. 5 (2): 23-29.

[2] Hoque, A., M.R. Talukder and M.N. Miaah, 1979. Effects of plant and row spacing on size, weight and yield of onion. Bangladesh J. Agric., 4: 147-150.

[3] Bond JA, TW Walker, PK Bollich, CH Koger, P sGerard (2005) Seeding rates for stale seed bed rice production in the mid southern United States. American Society of Agronomy 97(6): 1560-1563.

[4] Tan PS, TQ Khuong, NT Hoai (2000) Low cost technologies for rice production in the Mekong delta. Proceedings of the Paper presented at National Workshop on September 21- 23. Ho Chi Minh City, Vietnam p. 14.

[5] Derr, H.J. 1955. Seedbed density affects longleaf pine survival and growth. US Forest Service. Tree Planters' Notes 20: 28-29. 
[6] Shoulders, E. 1961. Effect of nursery bed density on loblolly and slash pine seedlings. J. For. 59: 576-579.

[7] Switzer, G.L. and L.E. Nelson. 1963. Effects of nursery fertility and density on seedling characteristics, yield, and field performance of loblolly pine (Pinus taeda L.). Soil Sci. Soc. Amer.Proc. 27: 461 -464.

[8] Shipman, R.D. 1964. Low seedbed densities can improve early height growth of planted slash and loblolly pine seedlings. J. For. 62: 81 4-81 7 .

[9] Mondal MMA, AB Puteh, MR Ismail, MY Rafii (2013) Optimizing plant spacing for modern rice varieties. International Journal of Agricultural Biology 15(1): 175-178.

[10]Kumar, H., J.V. Singh, A. Kumar and M. Singh, 1998. Studies on the effect of spacing on growth and yield of onion (Allium cepa L.) cv. Patna Red. Indian J. Agric. Res., 32: 134-138.

[11]Gupta, S.S.S. and M.A. Gaffer, 1980. Effect of row spacing and different combination of NPK fertilizer on the yield of onion. Bangladesh Hortic., 8: 8-12.

[12]Islam, M., 1988. Effects of different doses of nitrogen and plant spacing on the growth and yield of onion (Allium cepa L.). M.Sc. Thesis, BAU Mymensingh, Bangladesh.

[13]Rashid, M.A. and M.M. Rashid, 1976. Effect of spacing on the yield of onion. Bangladesh Hortic., 4: 18-22.

[14]Singh, K. and N.K. Jain, 1972. Response of onion (Allium cepa L.) to the application of N phosphorus and potassium on the sandy loam soil of Hissar. Indian J. Hortic., 29: 190-196.

[15]Pandey, U, B., Singh, L. Kumar, R. singh, L. kumar, R.and Rayehaudhury., S.P, 1991. Response of different level of N, P, K on the yield and quality of kharif onion. Recent Advances in medicinal, Aromatic and spice crops 1: 231-234.

[16]Bhonden, S. R., Ram, L., Pandey, U. B.and Tiwari, H. N. 1995. Effect of micronutrients on growth, yield and quality of kharif onion. Newsletter National Hort. Res. 14-15 (1): 16-20

[17]Zubeldia, A. and J.L. Gases, 1977. The effect of spacing and the number of stem on the earliness and total yield of tomato cultivars. Prod. Vegetable, 7: 73-97.

[18] Das L, Bhaumik E, Raychaudhuri U, Chakraborty R. Role of nutraceuticals in human health. Journal of Food Science and Technology. 2012;49(2):173-183

[19] Shimelis AE, Rakshit SK. Anti-nutritional factors and in vitro protein digestibility of improved haricot bean (Phaseolus vulgaris L.) varieties grown in Ethiopia. Inter J. Food Science \& Nutrition. 2005;56:377-387

[20] Prakash D, Gupta C. Role of phytoestrogens as nutraceuticals in human health. Pharmacology.2011;1:510-523

[21] Campos-Vega R, Loarca-Pina G, Dave Oomah B. Minor components of pulses and their potential impact on human health. Foodservice Research International. 2010;43:461-482

[22]Inaizumi, H., Singh, B. B., Sanginga, P. C., Manyong, V. M., Adesina, A. A. and S. Tarawali (1999). Adoption and Impact of Dry Season Dual Purpose Cowpea in the Semi-arid Zone of Nigeria. IITA IMPACT Series. IITA (International Institute of Tropical Agriculture), Ibadan, Nigeria, 14p.

[2 3] Das, B. C. and Dhyani, K. C. 1956. Influence of different spacing and nitrogen fertilization on growth and yield of onion. Phyton, 6: 47-56 [Cited from Hort. Abst., 26 (3): 2513, 1956].

[2 4]Gordon B.Bonan, 1993. Importance of leaf area index and forest type when estimating photosynthesis in boreal forests, journal of Remote Sensing of Environment. Volume 43, Issue 3, March 1993, Pages 303-314.

[2 5]Martin, F.W. and Ruberte, R.M. (1975). Edible leaves of the tropics. Antillian College Press, Mayaguez 
[2 6]Lim, E.S. and Hamdan O. (1984). The reproductive characters of four varieties of groundnuts (Arachis hypogaea L.). Pertanica.7: 25-31.

[2 7]Lee T. A, JR., Ketring, D. L. and Powell R. D. (1972). Flowering and Growth Response of Peanut Plants (Arachis hypogaea L. var. Starr) at two Levels of Relative Humidity. Plant Physiology. 190 -193.

*: Corresponding author, BANDUSHUBWENGE Denis: bandushubwengedeniis@ gmail.com or bandushubwengedenis@yahoo.com 